\title{
Editorial: Situations of Violence and Migration
}

\section{Marie-Antoinette Hily and Christian Poiret}

Translator. Katherine Booth and Alexandra Poméon O'Neill

\section{(2) OpenEdition}

\section{Journals}

Electronic version

URL: https://journals.openedition.org/remi/14781

DOI: $10.4000 /$ remi. 14781

ISSN: $1777-5418$

This article is a translation of:

Éditorial : Situations de violence et migration - URL : https://journals.openedition.org/remi/14326 [fr]

Publisher

Université de Poitiers

Printed version

Date of publication: 1 October 2020

Number of pages: $7-9$

ISBN: 979-10-90426-66-5

ISSN: 0765-0752

Electronic reference

Marie-Antoinette Hily and Christian Poiret, "Editorial: Situations of Violence and Migration", Revue européenne des migrations internationales [Online], vol. 36 - $n^{\circ} 1$ | 2020, Online since 01 October 2020 connection on 16 April 2022. URL: http://journals.openedition.org/remi/14781 ; DOI: https://doi.org/ 10.4000/remi.14781

This text was automatically generated on 16 April 2022.

(c) Université de Poitiers 


\title{
Editorial: Situations of Violence and Migration
}

\author{
Marie-Antoinette Hily and Christian Poiret \\ Translation : Katherine Booth and Alexandra Poméon O'Neill
}

1 With images of long lines of refugees fleeing combat zones, images of a slave market in Libya, images of bodies washed up by the sea or dotted along desert tracks, images of police harassment at the borders of Fortress Europe and images of camps and the violence of detention, the media, intellectuals, doctors, humanitarians and NGOs take it upon themselves to remind us on a daily basis of the extent to which violence and migration can be related. Yet, these images tell us nothing about the more discreet domestic and interpersonal violence, and in particular gender-based and sexual violence which can contribute to the decision to choose exile or which can make migration more difficult and complex. Nor do they tell us anything about the symbolic violence which compounds the violence suffered during migration when migratory and asylum policies tend to minimise, contest or deny the experiences suffered and lived through.

2 Violence cannot be reduced to objective facts nor can it in all probability be understood "objectively"; it also depends on the perception and experimentation of actors in situations and contexts. Thus, the same fact may or may not be characterised as violent depending on the norms and judgements of those assessing it and who therefore "attribute value" to it. Furthermore, it cannot only be apprehended "subjectively" as a suffered phenomenon: in their relationship to what they experience as violence, migrants develop strategies or tactics of avoidance and protection, to deal with dangers. How is it expressed in the accounts of migrants? For what purpose? To whom? And in what contexts?

3 Some of the topics addressed in this dossier are complementary to those explored in the issue of the Revue Européenne des Migrations Internationales (European Journal on International Migration) entitled "Dire la violence des frontières. Mises en mots de la migration vers l'Europe (Relating border violence: Putting migration to Europe into words)". ${ }^{1}$ The articles published there looked at the border as an object, questioned by 
discourses, mainly those of migrants, who experience in the course of their migratory journeys, the violence of the obstacles to be faced: the physical, social, legal and political borders endangering those who seek to cross them. This approach, by emphasising the production of discourses from different actors, filled a gap in research and contributed new elements to the understanding of migration processes. Thus, as Cécile Canut and Anaïk Pian conclude in their editorial: "putting the violence of borders and at borders into words provides a framework for understanding socio-spatial inequalities in a globalised world" (p. 16).

While their dossier provided valuable information on the ordeals of migrants and their accounts of violence, the articles published in this issue are more directly concerned with questioning the inhospitality and violence afflicting the mobility, whether by land or by sea, of men and women.

Without directly reporting on the many uses of the concept of violence which, even when adjectivised, as structural violence, institutional violence, interpersonal violence, racist, sexist, class-based violence, physical, psychological and symbolic violence, covers a wide range of meanings, at the risk indeed of diluting its sense, the authors of the articles published in this issue contributed to debates by focusing more directly on the practices and stages of migratory journeys. They look at questions related to the beginning of the migratory process, the hazards of the routes taken and settlement of variable duration. They also explore the central question of the role of the State and administrative rationales and their impact on migrant populations.

6 The article by the historian Yann Scioldo-Zürcher, which opens the dossier on "situations of violence and migration", focuses on the State of Israel's political role in the implementation of administrative rationales organising the migration and settlement of Jewish populations. The author shows that from the beginning of the 1950s, the Jewish Agency actively participated in organising the transfer and then settlement of migrants by imposing "legitimate administrative violence" on them. The selection and classification of migrants, the organisation of departures and the journey and the distribution within the national territory are all stages which are subject to a set of regulations aimed at serving the construction of the Israeli nation, to the detriment of individual situations and to the sole benefit of the construction of a country "understood as both a 'Jewish State' and a 'State for the Jews'". The Zionist migratory experience of the 1950s, which the author explores while freeing it of any moral standpoint, opens up the question of social normalisation, which in the case of Israel in the years following the recognition of the State, appears as the condition for the success of a national project in the context of an effort to respond to the urgency of a historical situation.

7 Laurent Faret describes another situation in which violence is linked to drug trafficking, social inequalities and the poverty embedded in the functioning of social groups. He situates his research in Mexico in the 2010s where "mobile populations" are particularly vulnerable, at the mercy of criminal groups or law enforcement bodies. The author focuses on state measures to strengthen control on migrant populations, in particular the repressive plan "Frontera Sur" (July 2014) which targets Central American migrants seeking to enter the United States. State violence and criminal violence represent a dual danger for these migrants who embark on a journey dominated by uncertainty and fear, but also the will to make the journey successful at all costs. 
8 Migrants' responses to the policies of two states, the United States and Mexico, are described in the article by Olga Odgers-Ortiz. Stopped by the wall, migrant populations are forced to choose between temporarily settling in Mexico while waiting to be able to leave, an irregular crossing which is a high-risk solution, or "redefining their migratory project" by settling in a Mexican city. For those who manage to reach the border, hardships endured throughout their journey are relativised to the point of being presented as the "price to pay". On the other side of the wall, they say they are disconcerted by the violence of the asylum application procedure, which is a form of violence that they had not anticipated. Resignation may be considered as another form of violence which has a price: the very high price of giving in to the rationale of border closures.

9 Émilie Adam-Vézina brings to light the experience of violence against women from sub-Saharan Africa living with HIV in France. She explores the intertwining experiences of violence, illness and migration and its effect on the trajectories of these women. Using empirical data collected through doctoral research, she shows that the linkages between these three components are revealing of the social processes which structure their social and migratory trajectories. Providing an account of the experience of violence demonstrates its impact on their migratory project and their health. While the links between migration and health are more widely known, the article deals with a little-studied dimension, that of the complex relationship between a health condition altered by HIV/AIDS, the migratory experience and the experience of violence. The author distinguishes three forms of violence experienced by these women, generalised, institutional and interpersonal, which manifest themselves at different stages of the migratory journey: those suffered in the country of origin, which motivate their departure, then on the roads where they increase their vulnerability to the risks of contamination, and finally in France, where they increase the precarity of their situation and reinforce the uncertainty regarding the acquisition of residence rights.

10 Oriana Philippe's legal column entitled "L'arme juridique aux confins de la France et de l'Italie (Legal Weapon in Action at the French-Italian border)" shows how the French authorities use the Schengen Borders Code to practice "normative circumvention" according to the situation. For example, in 2015, following the terrorist attack, France with the adoption of the state of emergency - formalised the practice of national border controls. Faced with these circumventions, which hinder the principle of free movement within the Schengen area, and at a time when solidarity is being strengthened at the French-Italian border, with the conviction of Cédric Herrou in particular, human rights associations have responded by using the law. A greater command of the law in the context of the confrontation with the State has become a weapon, first used defensively and then offensively to pursue legal actions.

11 Some state institutions therefore appear, in the articles of this dossier, as major actors in the processes of construction of the "violent worlds" encountered by migrants on their migratory journeys. 


\section{NOTES}

1. Cécile Canut, Anaïk Pian and Véronique Petit (co-ordinators) (2017) Dire la violence des frontières. Mises en mots de la migration vers l'Europe, Revue Européenne des Migrations Internationales, 33 (2-3).

\section{AUTHORS}

\section{MARIE-ANTOINETTE HILY}

Sociologist, MIGRINTER, University of Poitiers/CNRS (French National Centre for Scientific Research), MSHS (Research Centre for Human and Social Sciences), Bât. A5, 5, rue Théodore Lefebvre, TSA 21103, 86073 Poitiers cedex 9; marie-antoinette.hily@orange.fr

\section{CHRISTIAN POIRET}

Sociologist, University Lecturer HDR (authorisation to direct research), URMIS (Migration and Society Research Unit), University of Paris/CNRS/IRD (French National Research Institute for Sustainable Development), casier 7027, 75205 Paris cedex 13; poiret@u-paris.fr 